\title{
言語に着目したサイバー時代における 新たな都市序列 ${ }^{\dagger}$
}

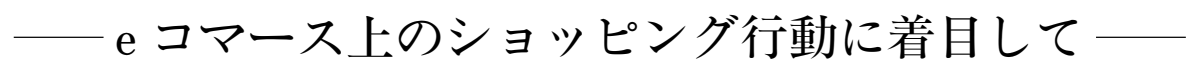

谷口守*, 松 中亮 治*, 安 藤 亮 介**

\section{1. はじめに}

自動車や高速鉄道などの高速交通機関が普及してまだ 50 年程度しか経過していないが, そのこ とによって以前と比較すると都市の形態や序列は大きく変化した。このような新しい技術の登場 に従って，我々はその住まい方，暮らし方を急速に適応させ，その便益を享受するとともに，以 前には想像できなかった地域の浮沈や新たなビジネスニーズに後から気づくことになる。例をあ げれば，現在の横浜市はわが国第 2 の都市として大きく発展を遂げている（都市序列としては高 い）が，江戸時代末期の横浜は寒村であった（都市序列が低かった）ことが知られている。その 間，港湾，高速道路，新幹線といった交通インフラの整備が実空間における横浜の序列を引き上 げるのに大きな役割を果たしたことが容易に類推できる。

ちなみに, 現在における IT 関連の技術発展は, 上述したように, 以前高速交通機関がおかれて いた立場とよく似ており，将来的にこれら実空間における交通体系・基盤を凌駕する可能性さえ 内在している1。実空間において横浜の序列が変化した以上に，サイバー空間を通じた都市序列の 変化が生じる可能性を否定できる根拠はなく，その意味でサイバー空間における都市序列の検討 を今行うことの重要性は高い。また，実空間での東京一極集中が問題とされるように，サイバー 空間上でも新たな序列化に伴う空間分布の偏りが引き起こす問題が発生する可能性がある。しか し，社会における現時点での認識は，IT 化の進展によって「どのような場所からも一瞬で好きな 場所にアクセスできる」という，あいまいな「夢」として語られる以上のものは少ない。空間利 用の適正化という観点から，サイバー空間における極端な活動の集中が発生する可能性は全く議

†本論文は日本地域学会第 41 回年次大会における発表論文をもとに加筆・修正したものである。大会での発 表漈し, 三友仁志教授 (早稲田大学), 光多長温教授 (鳥取大学) より貴重なコメントをいただいた。ま た, 本研究の実施に際しては財団法人国際コミュニケーション基金より調查研究助成を得た。ここに記して 謝意を表す。

$*$ 岡山大学

** 岡山大学大学院自然科学研究科

1 奇しくも2004 年には, わが国の一大娛楽産業といえるプロ野球における多くの球団が，大手私鉄・流通企 業（近鉄・西武・ダイエー）から IT 企業（ソフトバンク・楽天・ライブドア他）へと売却・再編される動き が加速したことは記憶に新しい。このような都市の空間形成を実質的に担ってきた大手私鉄・流通企業か ら, IT 空間 (サイバースペース) 構築に励む IT 企業への主役の交代は, 都市序列変革における大きな転換 点に我々が立っていることの証左となる。 
論されていないのである。効率的な基盤整備と豊かな社会の実現のためには，このような IT 技術 の導入に伴って生じる社会や地域の構造変化を事前に察知し, サイバー空間内において極端に 偏った形で急速な都市序列変化が生じることのないよう配慮を行ったり，実空間における都市活 動とのバランスに留意することも必要となろう。

なお，かつての産業革命や高速交通機関の普及がそうであったように，このような IT 技術進展 は実際に都市の形態・序列を既に根本的に変えつつある。IT 技術の発展に伴う空間抵抗の解消に より，実空間での距離抵抗がもたらすバリアは大きく解消された。しかし，物理的な抵抗が解消 する反面，ネット検索などで使用する言語の違いが新たな（むしろ「残された」と表現すべきか） 抵抗として意味を持つ可能性がある。そこで本研究では，まず主要な「言語圈」（j）ごとに言語圏 を構成する「都市」（i）に着目し，都市人口構成（現序列）とネットサイト数構成 (将来序列の代 理指標）を比較することで言語圏内部での都市序列の変化の可能性を探る。また，その一方で，よ りグローバルな観点から言語の違いが抵抗とならない可能性についても言及する。具体的には,地 球全体を境界の無い単一の圈域として捉え，グローバルな観点からサイバー上でどの「都市」（i) がアクセスされるポテンシャルが高いか（Globality $G_{i j}$ ) を定量的に検討する。これらの結果を 総合することで，サイバー時代における都市序列変化の可能性について考察を加える。

\section{2. 本研究の位置づけと分析の全体構成}

\section{1 本研究の位置づけ}

IT 技術の浸透が及ぼす影響に着目した研究は数多いが, それらのほぼすべては短期的な視点か ら個人行動への影響を解明しょうとしたものである（[13] [19]）。しかし，長期的な視点から見 た場合, IT 技術がもたらすサイバースペースの出現が都市の序列や構造を如何に改変するかにつ いての研究は少ない。この問題は本質的で，我々の未来を大きく左右する課題であるにも関わら ず，実証的な実験デー夕等を得ることが難しいことが理由である。

サイバー空間の定性的な性格に関する検討 ([7])，及び IT 化に伴って空間的な抵抗が消滅する ため，諸活動の空間的な分散が促進されるという指摘はある（[2]［8]）。また，地域性の崩壊に 伴う抽象概念として，都市のネオ・フォーマリズムの議論も見られるようになっている([3])。し かし現段階では必ずしもこのような分散化や構造変化が十分な実証データとともに示されている わけではない。

以上のような問題意識のもとで，オフィスを中心とした業務活動に関してはIT 化に伴う都市 形態への諸影響について幅広い観点から検討が積み重ねられてきた ([1][15][16][18][21][22])。 しかし，このような都市における業務活動を一方の翼とすれば，買い物行動などに代表されるも う一方の翼である自由活動については, IT 化と関連してょうやく検討が進められるようになった ばかりである ([12] [17])。この自由活動分野に関連して我々の研究グループでは現在までサイ バースペース上での自由買い物行動（サイバーウォーク）に焦点をあてた検討を行ってきた ([20])。具体的には, IT 化により買い物行動が実際のタウンスペースからサイバースペース上に 
どれだけ移行し，それと同時にアクセス先がどこへ変化するかを，実際にサイバーウォークを被 験者に対して行わせることで検討した(サイバーウォーク実験)。結果として，現在地方都市の街 なかで行われているタウンウォークが，東京圏へのサイバーウォークに転換する実態を定量的に 明らかにした。換言すると，わが国国内における IT 化に伴う長期的な都市序列変化の可能性とし て，分散化よりもむしろ一極集中が加速されることについて警鐘を鳴らした。

この研究では主にわが国における日本語ショップサイトのみを分析対象としたが，サイバース ペースには国境や税関があるわけではない。ワールドワイドな観点から都市の序列の変革を議論 しなおす必要がある。それに加え，IT 化に伴って空間的な抵抗は解消する反面，当初は予想して いなかったサイバースペースのみに特有な新たな抵抗（バリア）が発生することを考慮する必要 がある。現在まで全く着目されていないが，世界において分析を行う場合，サイバースペース利 用者がどのような言語を通じてサイバーウォークを行うかによって，利用者の行動圏は明らかに 異なる制約を受けることになり，このような言語バリアの存在が将来的にはサイバースペースに おける各都市の盛衰に大きな影響をもつものと類推される。ただ，より一段と社会のグローバル 化が進展した場合，このような言語バリアの影響が大きくならない状況も考えられる。近年日本 で英語の教育が進んでいるように，将来的に自国語以外の言語でのサイバーウォークも行われる 可能性があるためである。そういった場合，サイバースペースとして地球上の全ての地域を境界 のない単一のものとして捉えるという試みも必要となろう([14])。そこで本研究では, 解空間を 知る上での端点として言語の違いが抵抗を持つ場合と持たない場合の，二つの前提のもとに，そ れぞれの条件のもとでの検討を行った。

\section{2 分析の全体構成}

本研究では，まず，使用する言語の違いによる抵抗がある場合を考慮し，複数の言語圏内にお いて，どの都市にインターネットでの買い物を目的としたアクセス（サイバーウォーク）が集中， または分散するかに着目した。そこで各都市のショップサイト数割合（ $\left.\chi_{i j}\right)$ と，言語圏内の総数 に対する人口割合 $\left(\gamma_{i j}\right)$ を明らかにし，比較した。そして，各都市 ${ }^{2}$ のショップサイト数割合 $\left(\chi_{i j}\right)$ をサイバースペース上の都市規模，人口割合 $\left(\gamma_{i j}\right)$ を実空間上の都市規模とし，ランクサイズルー ルによる都市規模構造の比較分析を行った。次に，使用する言語の違いが抵抗とならず，地球全 体を単一の圈域として捉えた場合を考慮した。各都市が世界からどれだけアクセスさる潜在的可 能性があるかを, 本研究では Globality $\left(G_{i j}\right)$ と名付け, 各言語圈における各都市のショップサイ 卜数割合 $\left(\chi_{i j}\right)$ に，対象言語圏全体 $(T)$ における各言語圏のショップサイト数割合 $\left(\delta_{j}\right)$ で重み 付けすることで算出した。そしてこの Globality $\left(G_{i j}\right)$ に影響を与えている要因を，重回帰分析を 用いたモデル化を通じて定量的に分析した。これらの分析から，将来のサイバー時代における新 たな都市序列の可能性を検討する。図 1 に本研究における分析のフローを示す。

2 実際の分析結果の表現にあたっては,グラフが極端な形にならず, 傾向がわかりやすく把握できるように集 計の単位を適宜地域や国とした場合もある。 


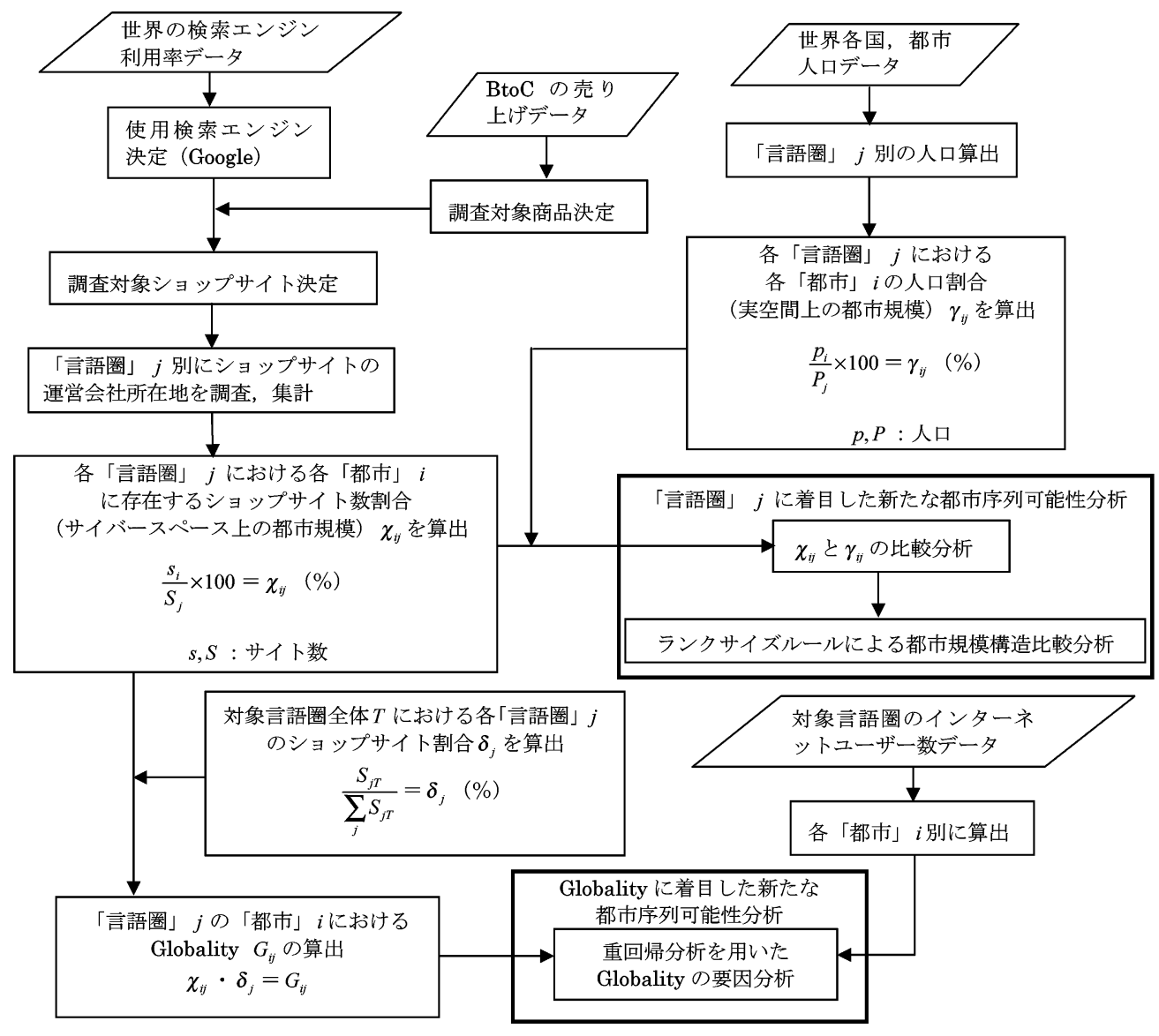

図 1 分析のフロー

\section{3. ショップサイトの調査方法}

\section{1 調査概要}

本研究では, 消費者がインターネット上での買い物行動(サイバーウォーク)を行う際に，1.ま ず購入する (購入したい) 商品を決定し，2．その商品をどうやって（どの検索エンジンを使って） 探すかを決定し，3．どのショップサイトで商品を見るかを決定する，という 3 つの決定行動から 構成されると仮定した。それぞれの決定行動について, 本研究では次のような考え方を採用した。 1. インターネットショッピングの売り上げデータから ([4])，13 項目の商品を分析対象とする。 2. 世界の検索エンジン利用率データから, 世界での利用シェアが $46.5 \%$ で 1 位となっている検索 エンジン Google を使用する（[9]）。3．消費者がよくアクセスするショップサイトを判断する指 標として Google の PageRank を用いる。PageRank とは Google 独自開発の検索アルゴリズム で，その原理は「その Web ページが外部からどの程度リンクされているかによってページの重要 性を判断し，そのページにリンクしている外部ページを自動的に順位付ける。」いうことである。 
ブランドや，人々のそのサイトに対する信用などもこの PageRank で評価されると考えられる ([6])。本研究ではこのページランクの高い（良質な）ページはよくアクセスされると考え，ラン クの高いショップサイトの所在地を調査対象とした。なお，上記した $46.5 \%$ という数值はあくま で検索エンジンとしての利用シェアであり，それが本研究で対象とする e コマース上のショッピ ング行動のシェアと等しい訳ではない。ただ，その間には一定の相関があることが類推される。ま た，実際のサイバー空間におけるトラフィック量そのものを分析することが理想ではあるが，本 研究のような世界規模の現象を実査したり実験したりすることは非現実的であり，その概念から PageRank がトラフィック量の代用指標として利用し得ることに着目した。

また，サイバー空間上のショップにおいては，サーバの所在地，出荷地，受注機能が別々に所 在する可能性もあり，このうちサーバなどはそのショップと本来無関係な場所に設置され，その ショップの業務とは実質的な関係がないことも考えられる。このため，本研究では実際に商品を 取引する場所を対象とすることで統一的な所在地の特定を行うこととした。具体的にはショップ サイトに表記されている住所が，実際に商品を送り出している場所ではない可能性があることを 考慮し，対応させる住所はそのショップサイトへ商品を返品する場合の住所を優先して調査して いる。返品先の住所が表記されていない場合は，ショップサイトが住所として表記している住所 が対応すると考えた。

\section{2 調査対象言語圏の決定基準}

本研究では調査の対象とする言語圈を以下の基準をすべて満たすことを条件とした。

基準 1：その言語を使用する国および地域が多数存在する。

基準 2 ：その言語圈におけるインターネットユーザー数の，全世界ユーザー数に対する割合が 高い。

基準 3 : ショップサイトの数が統計的分析を行う上で十分な数がある。

基準 1,2 については，今回本研究では「国境を越えたサイバーウォーク」が行われる可能性の 検証を中心とした調査を行うこと目的としているので，言語を使用する国および地域が 3 力国以 上，ユーザー数割合を $3 \%$ 以上の言語圏を対象とした([11])。基準 3 については，後に述べるよ うに各調查対象商品 13 項目につき 20 サイトを調査するため最低 260 サイト必要であるため，こ の数字を参考に本研究ではオンラインショップカテゴリのショップサイトが 300 を越える言語圏 を対象とした。この 3 つの基準を当てはめた結果，3つの条件をすべて満たす言語圈は，英語圏， ドイツ語圏，スペイン語圏，フランス語圏となった（なお紙数の関係上，フランス語圏の分析結 果は本論文では一部割愛している)。また，日本語圏も検討対象として加えこれらの 5 つの言語圏 を本研究の対象とする。

\section{3 調査商品項目の決定基準}

調査項目については, インターネットショッピングの売り上げ商品データ ([4]) から, 調查対 
象商品を以下の 13 項目に決定した。
1. 本
2. 衣類
3. 衣類小物（アクセサリ）
4. 家具 5. 装飾品（インテリア）
6. CD 7. DVD

8. おもちゃ

9. ゲーム (コンピュータゲーム

ム、゙ードゲーム等)

10. 食品

11. 飲料

12. 健康

13. 美容

\section{4 各国 Google のオンラインショップカテゴリ}

地域および国別の Google は全部で 73 個あり (2003 年 9 月時点), そのうち 69 力国の Google のオンラインショップカテゴリはクリックすると最初は全て，英語，ドイツ語，フランス語，ス ペイン語で構成されたいずれかのオンラインショップカテゴリのページにアクセスする。(日本語 で表示されるのは日本だけ)つまり，Google を用いてオンラインショッピングをする場合，日本 を除いた 68 力国全ての国が，4 つのページのどれかに最初アクセスするということである。もし 言語がその国の主要言語でなくても，始めにアクセスしたぺージから，ディレクトリ項目で地域 および国を限定，つまり検索の幅を地域および国に限定しないかぎりその国の言語では表示され ないという構造になっている。よって，英語を例に考えると，本研究では通常主に国民が使用し ている言語が英語ではないが, まず英語圏のオンラインショップカテゴリにアクセスする国は, 全 て英語圏のオンラインショップカテゴリでサイバーウォークを行う可能性があると考え，これら の国々を全て英語圈とみなした。

\section{5 オンラインショップカテゴリの構成}

Google のオンラインショップカテゴリにアクセスすると, まず以下に示した図 2 上部のページ にアクセスし，ここから検索を開始することになる。この図からわかるように最初のページでは

\begin{tabular}{|c|c|c|}
\hline \multicolumn{3}{|l|}{ カテニリー } \\
\hline $\begin{array}{l}\text { ショッピングモール(40) } \\
\text { スポーツ(247) } \\
\text { ファッション(892) }\end{array}$ & $\begin{array}{l}\text { 地域別・エスニック (254) } \\
\text { 多品目販売(67) } \\
\text { 娛楽(204) }\end{array}$ & $\begin{array}{l}\text { 電谷製品(68) } \\
\text { 音楽(146) } \\
\text { 食品(1125) }\end{array}$ \\
\hline \multicolumn{3}{|l|}{ ファッション } \\
\hline \multicolumn{3}{|l|}{ カテジリー } \\
\hline $\begin{array}{l}\text { カジュアル(118) } \\
\text { ティーンズ(6) } \\
\text { ファッション雑貨(211) }\end{array}$ & $\begin{array}{l}\text { 下着(51) } \\
\text { 和服(48) } \\
\text { 地域別・エスニック(92) }\end{array}$ & $\begin{array}{l}\text { 水着(11) } \\
\text { 男性(50) } \\
\text { 目的別(29) }\end{array}$ \\
\hline \multicolumn{3}{|l|}{ ウxプページ } \\
\hline $\begin{array}{l}\text { エプロンママの井戸端会議 } \\
\text { エプロン尃門の通販。 } \\
\text { 縫物屋ちくちく http://www } \\
\text { マット, 赤ちゃんのおくるみ }\end{array}$ & $\begin{array}{l}\text { http://www.otk-apron.com } \\
\text { 2.ocn.ne.jp/ tick/index.html } \\
\text { タ, 化粧ポーチ等すい゙て手縫いパ }\end{array}$ & \\
\hline
\end{tabular}

図 2 日本 Google のオンラインショップページ（ファッション項目をクリックした場合） 
ショップサイトが取扱商品のジャンル別に，おおまかに分類されており，分類の横にはその分類 内のショップサイト数が表示されている。この商品分類から，例えば「ファッション」をクリッ クすると図 2 下部に示したようにページ上部に細かい商品分類項目が表示され，ページ下部には ページ上部の細分化された商品分類項目に分類できないぺージ（複数種類の商品を扱っている店 が多い）が表示される。そして，このページの上部の細かい商品分類項目をクリックすると，同 じようにさらに細かい商品分類項目とそれらに分類できないページが表示され，ある程度ぺージ 数が絞れるまでこのページ構成が繰り返される。

そしてある程度商品項目を限定しページ数が絞れると検索結果ページのみの表示となり，それ 以上は商品項目を限定することはできなくなる。このように商品分類項目を選択することで，あ る程度検索する商品を絞り込むことができる構成になっている。また，商品を絞り込むことがで きる項目の種類および数は総ショップサイト数の違いから言語圈によって異なる。

\section{6 調査対象サイトの決定方法}

3.5 で述べたように各調査対象商品項目で細分化できる商品項目の種類や数は言語圈によって 異なる。よって，できるだけ調査対象商品項目内におけるぺージランクが高い全てのショップサ イトの所在地を把握するために, 1 つの対象商品項目内の, 全ての細分化項目からショップサイト をピックアップできるようなルールを定め，調査した。そのルールは，対象商品項目内の細分化 項目のサイト数に比例した数だけ，その細分化項目内のページランクの高いサイトの所在地を調 査するというものである。また，1つの調査対象商品につき，ページランクの高い 20 サイトの所 在地を調査する。この数は, 実際にショップサイトをいくつか調査して 1 つの調査対象項目にお ける所在地分布が大体把握できる数と判断し, 決定した。

\section{4. 分 析 結 果}

\section{1 「言語圏」に着目した新たな都市序列変化可能性分析の結果}

分析結果を以下の図 4 から図 11 に示す。また，図 8 から図 11 ではランクサイズルールの概念

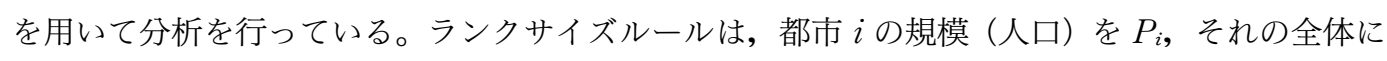
おける順位を $R_{i}$, 正のパラメータ $q$ をとすると,

$$
R_{i} \times P_{i}^{q}=\text { 一定 }
$$

とするのが，一般化されたランクサイズルールである（分析対象スケールは「都市」で統一）。ラ ンクサイズルールは，(1)式において $q=1$ とした特殊ケースである。世界各国の都市人口データ によって統計的に推計された $q$ の值は, ほぼ 1 であることが広く知られている。しかし,なぜ 1 に なるかは十分に解明されていない $([10])$ 。この両辺を常用対数に変換したものが, 横軸に順位, 縦軸に都市人口規模をそれぞれとったグラフ上で直線的に表された場合，ランクサイズルールに あてはまるといえる。また, 多くの国がこのルール通りにはなっておらず，都市の人口規模と順 


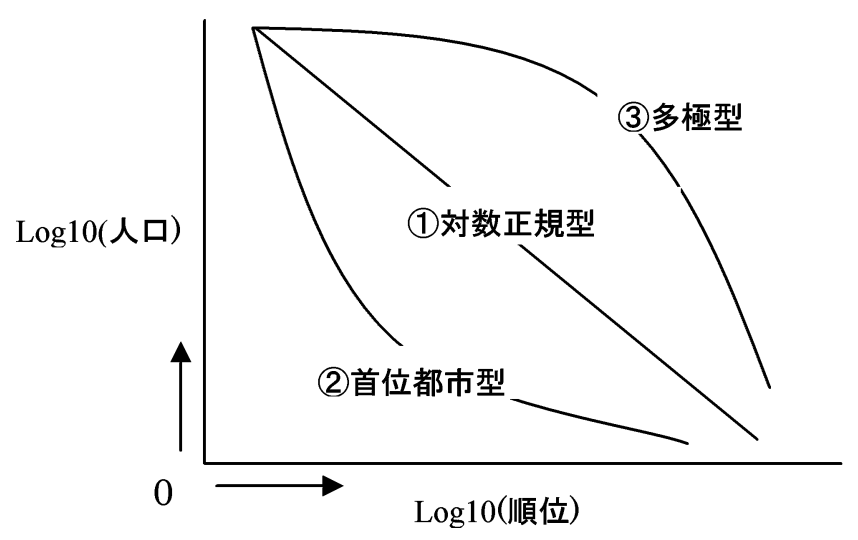

図 3 ランクサイズグラフの基本型

位の関係には以下の図 3 に示すような類型があることが明らかになっている。

(1)のようなグラフは対数正規型と呼ばれ，ランクサイズルールに当てはまる型である。(2)のよ うなグラフは首位都市型と呼ばれ，首位都市と 2 位都市の人口の格差が開いている場合このよう なグラフになる。(3)のようなグラフは多極型と呼ばれ，同じくらいの規模の都市が複数存在する 場合このようなグラフになる。

本研究では各言語圏で最もショップサイト数の多かった, 日本, アメリカ, ドイッ, フランス, スペインにおいて，各都市における人口を実空間上での都市規模，ショップサイト数をサイバー スペース上での都市規模とみなし，この 2 つの空間における都市規模構造の比較を，ランクサイ ズグラフを作成することによって行った。なお，本論文は言語圏での分析を一つの主眼とするが， 分析の結果各言語圏において特定の国が非常に高いショップシェアを占めていたため，このラン クサイズルールの分析では各言語圏において最もシェアの高かった国を選んで分析を行った。

分析結果から以下のようなことが読み取れる。

1) 図 4 から日本語圈では, 東京 23 区の人口とショップサイト数の割合の差が特に大きいこと から，日本では東京 23 区にショップサイトが一極集中しているといえる。

2）図 5 から英語圏では,アメリカ合衆国, イギリス,オーストリア,カナダの 4 つの国にショッ プサイトが多い。特にアメリカ合衆国に大幅に集中しており，その中でも特にカリフォル ニア州，ニューヨーク州に多いことがわかり，英語圏ではほとんどがアメリカ合衆国へア クセスすると考えられる。また，インド，パキスタンはその人口規模に対して，ほとんど ショップサイト数がないことが読み取れる。

3）図 6 からドイツ語圏では，ドイツのベルリン，ミュンヘン，ハンブルグ，シュツットガル ト，ヘッセン州の一部の地域にショップサイトが集中しており，その他の地方には集中し ていないことがわかる。

4）図 7 からスペイン語圏では，マドリードとバルセロナの二つの都市にショップサイトが多 いことがわかる。 
5）図 8 から日本の人口のグラフは対数正規型，ショップサイト数のグラフは首位都市型と なっている。このことから，日本国内においては，人口に比べて，ショップサイトは東京 に一極集中していることがわかる。

6) 図 9, 図 10 からショップサイト数のグラフがアメリカ合衆国内ではほぼ対数正規型，ドイ ツ国内では多極型になっていると読み取ることができ，これら二つの国ではサイバース ペース上の都市規模が同じぐらいの都市が複数，段階的に存在していることがわかる。

7）図 11 からスペイン国内においては，ショップサイト数は人口の分布に比べ 1 位，2 位の都 市（マドリードとバルセロナ）の二つの都市に集中していることがわかる。

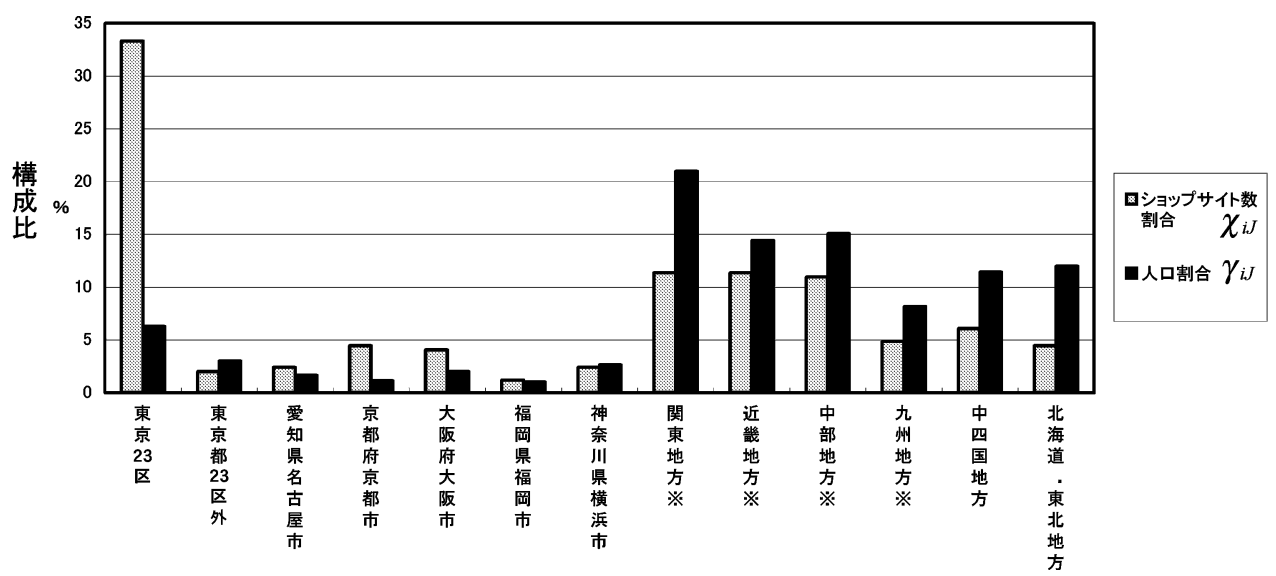

図 4 日本 (J) における都市および地域別ショップサイト，人ロシェア

注） ※人口, サイト数は, 関東地方は東京, 横浜市, 近畿地方は京都市, 大阪市, 中部地方は名 古屋市，九州地方は福岡市の数を除いている。

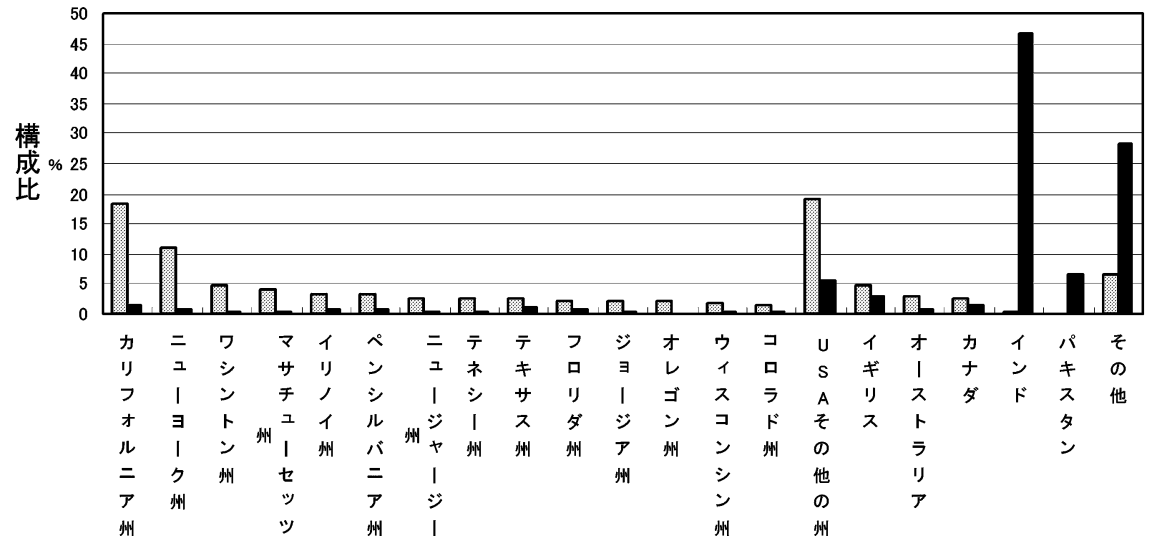

図 5 英語圏（E）における州および国別ショップサイト，人口シェア 


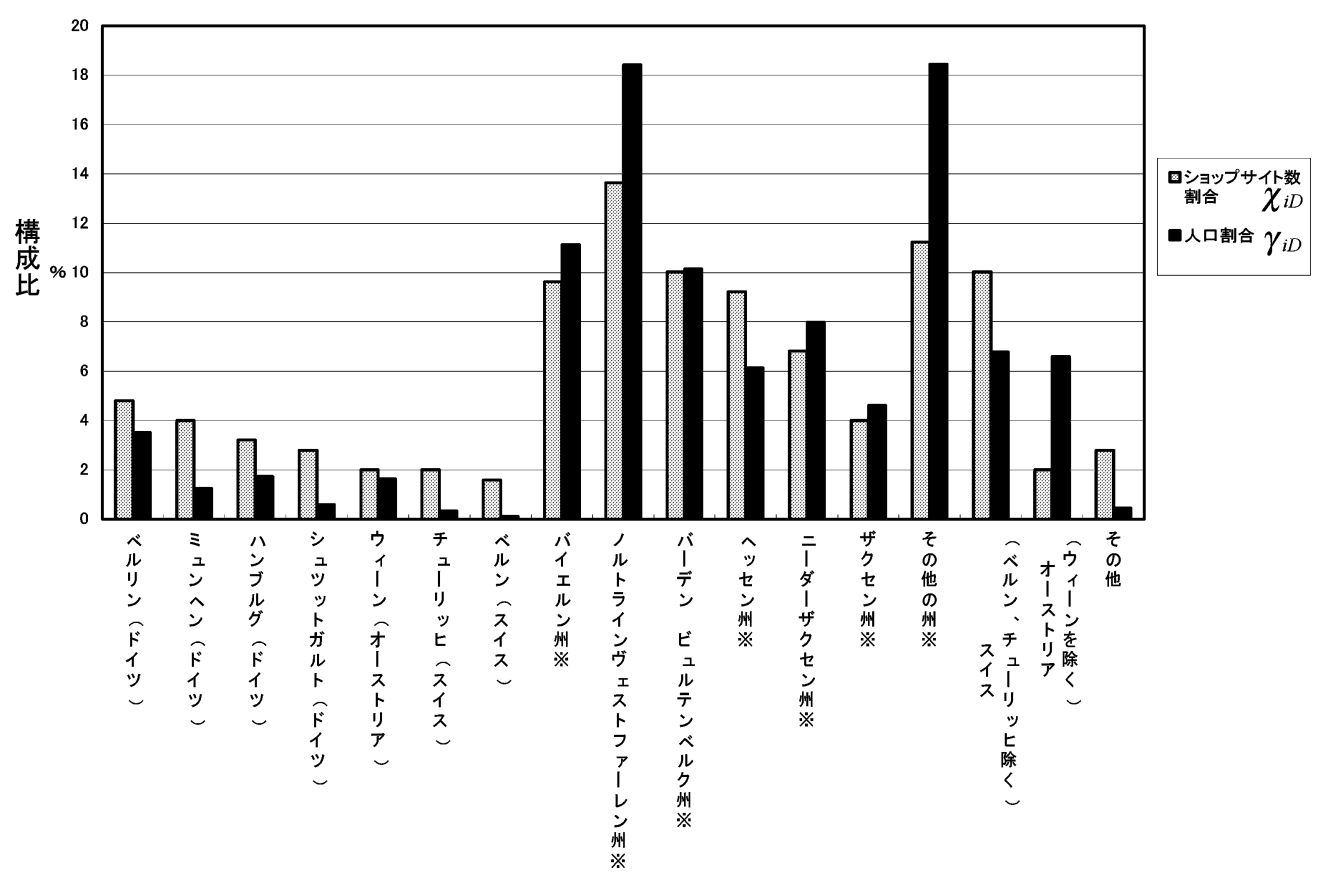

図 6 ドイツ語圏 (D) における都市および地域別ショップサイト, 人口シェア

注） ※は全てドイツの州。なお少イト数, 人口割合は，バイエルン州はミュンヘン，バーデン・ ビュルテンベルク州はシュツットガルトの数を除いている。

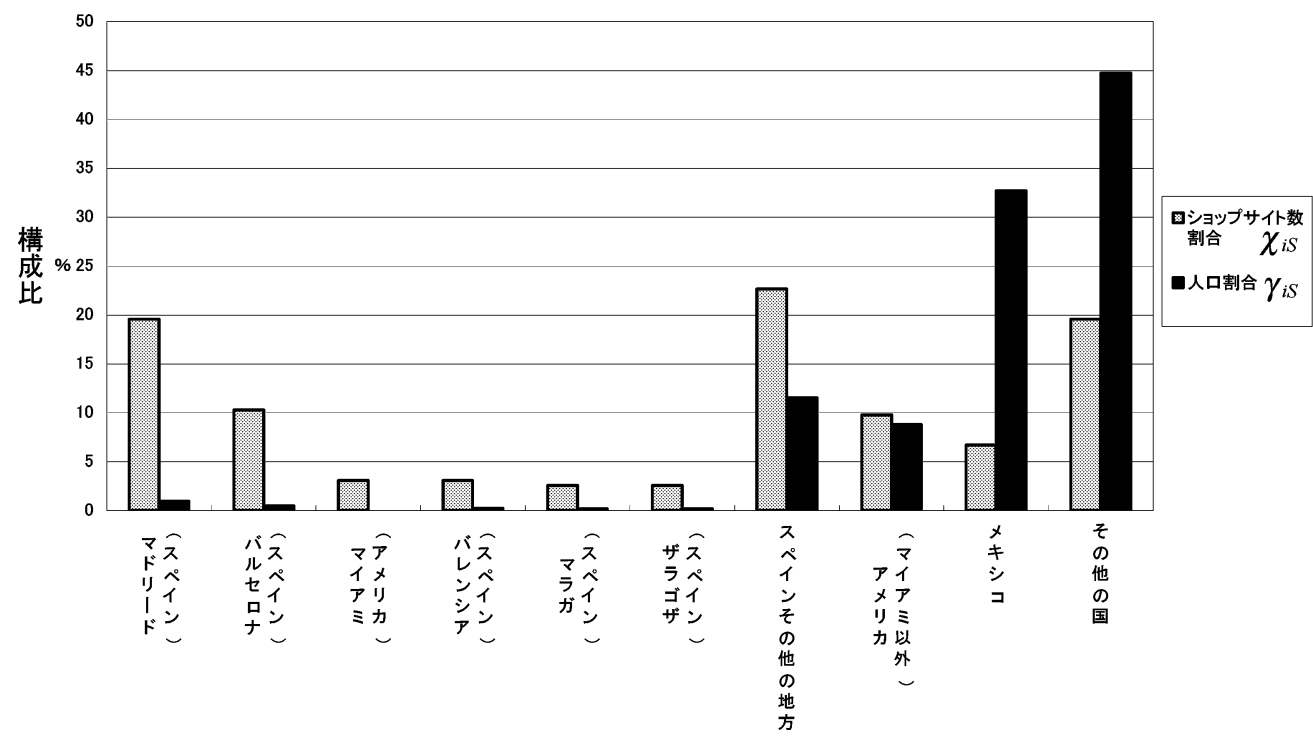

図 7 スペイン語圏（S）に扔ける都市および地域別ショップサイト，人口シェア 


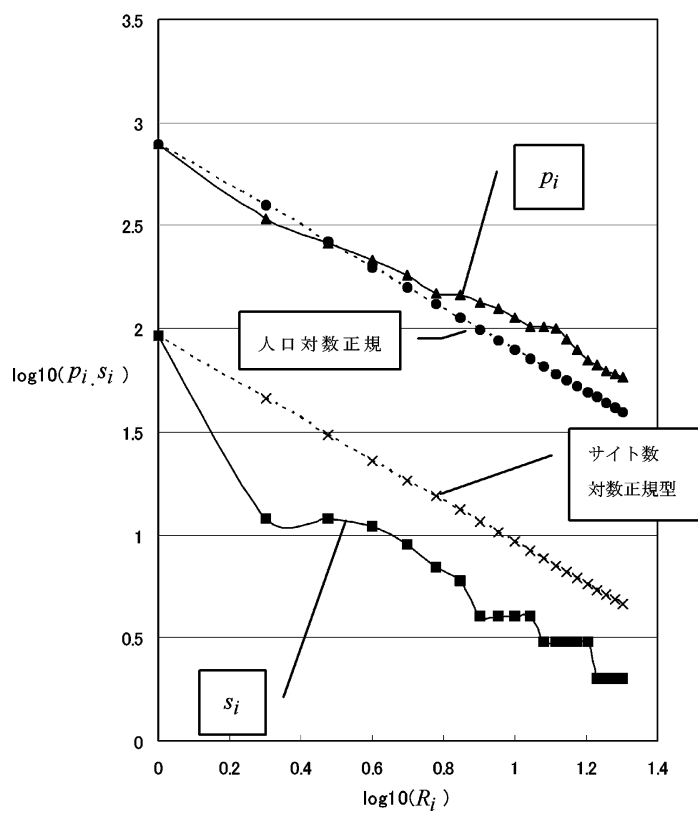

図 8 日本の人口とショップサイト数におけるラン クサイズグラフの比較

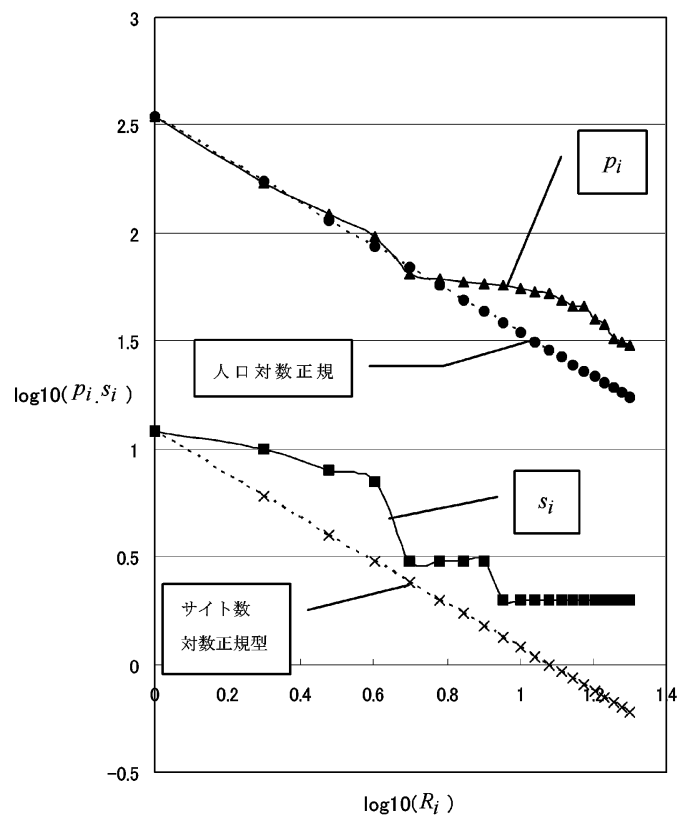

図 10 ドイッの人口とショップサイト数における ランクサイズグラフの比較

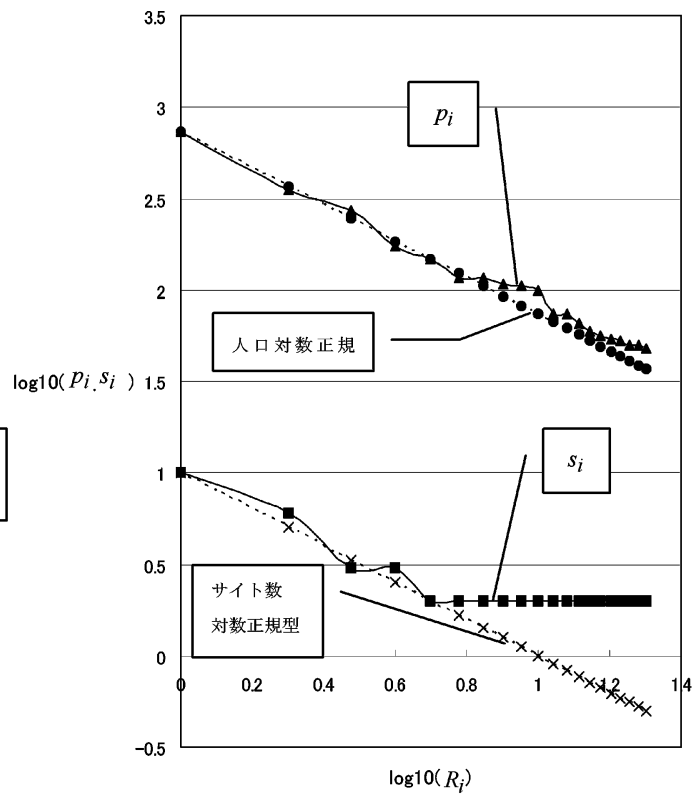

図 9 アメリカの人口とショップサイト数における ランクサイズグラフの比較

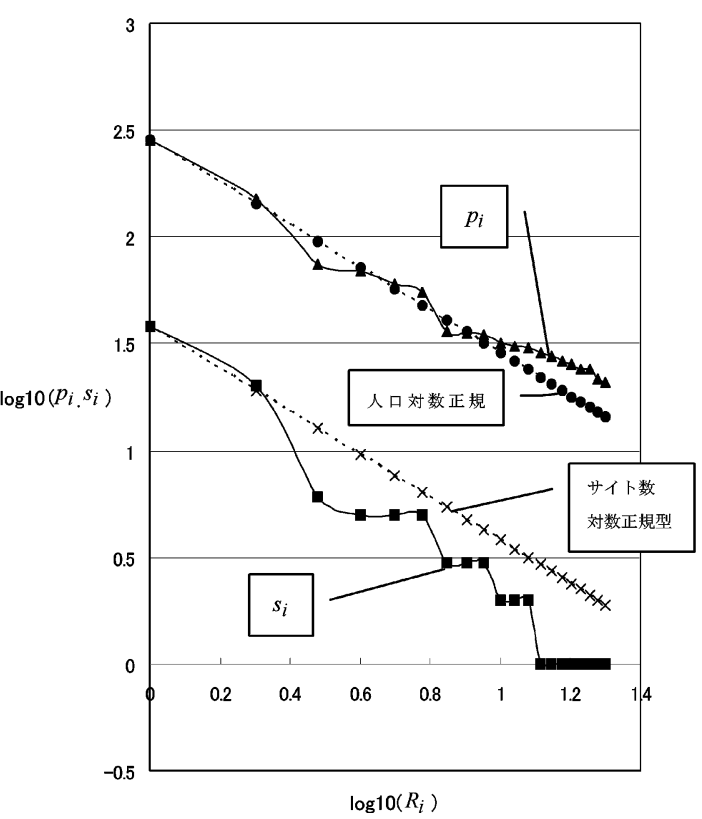

図 11 スペインの人口とショップサイト数におけ るランクサイズグラフの比較 


\subsection{Globality に着目した新たな都市序列変化可能性分析の結果}

各言語圏における各都市のショップサイトが，対象とした 5 つの言語圏全体からどれだけアク セスされ得るか，つまり各都市のグローバルセンターとして（IT 時代において，序列が高くなり 得る）資質を本研究では Globality（グローバリティー $G_{i j}$ ) と名付けた。そして，この Globality を式 (2) のように，各都市のショップサイト割合 $\left(\chi_{i j}\right)$ を，対象言語圏全体 $(T)$ における各言 語圏のショップサイト割合 $\left(\delta_{j}\right)$ でウェイト付けすることで算出した。算出結果を図 12 に示す。

$$
G_{i j}=\chi_{i j} \delta_{j}
$$

そして, 各都市が Globality $\left(G_{i j}\right)$ を備えるための周辺環境について，重回帰分析を通じて検討 した。被説明変数は 5 つの言語圏における各都市のショップサイト割合（ $\left.\chi_{i j}\right)$ とし，用いた説明 変数および変数を投入して得られたモデル集計，係数を表 1 に示した。

このモデルの説明力を表す指標に值する決定係数および自由度調整済み決定係数は約 0.98 と 高く，精度の高いモデルであると言える。

Globality $\left(G_{i j}\right)$ 説明モデルから明らかになったことは以下の通りである。

1) Globality（ $\left.G_{i j}\right)$ には普及率よりも，各都市に存在するインターネットユーザー数という絶 対数が影響していることがわかった。このことから，地域内にサイバースペースにアクセ スする人数が多い地域ほど，ショップサイトが多いという解釈が可能である。

2） 5 つの言語圏において英語圈の Globality $\left(G_{i j}\right)$ が高いが，それはアメリカ合衆国，カナダ， オーストラリアの三カ国で特別多く，イギリス，インドなどの旧大陸の国々では新大陸の 三力国に比べて多くないことが明らかになった。

3）アメリカでも最も進んでいると言われる IT 産業集積地があるカリフォルニア州や，世界 の経済の中心でもあるニューヨーク州はやはり特別に Globality $\left(G_{i j}\right)$ が高くなっているこ

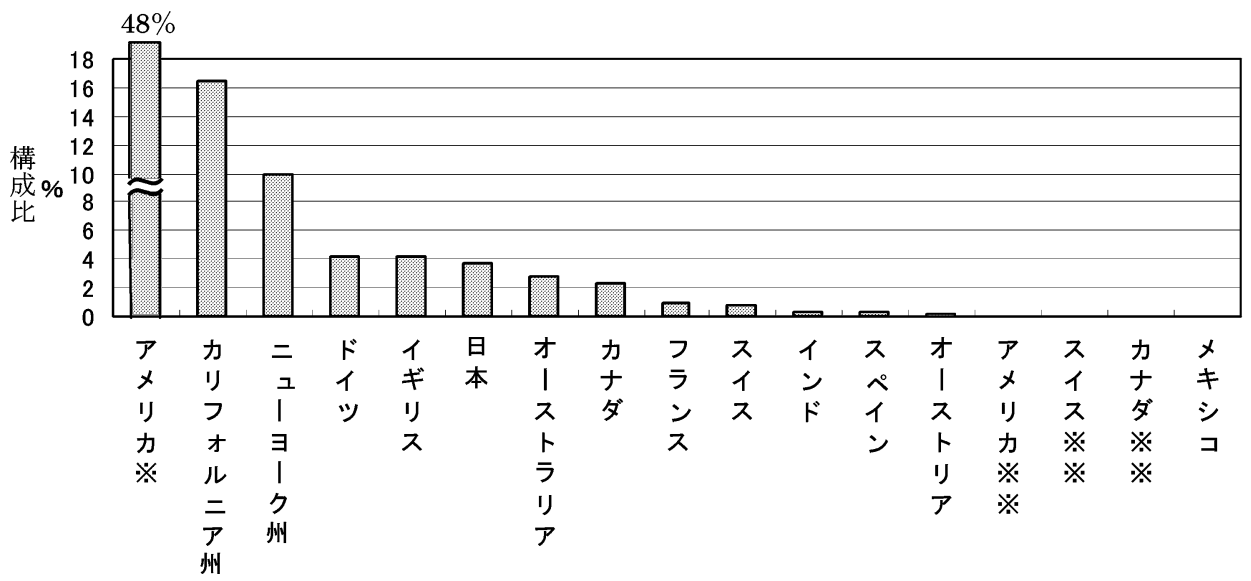

図 12 各国の Globality

注） ※は NY 州，CA 州の值を除く

※※は,アメリカはスペイン語使用人口分, スイス, カナダはフランス語使用人口分 
表 1 Globality 説明モデル（重回帰分析）

\begin{tabular}{|c|c|c|c|c|c|}
\hline 記号 & 説明変数名 & $\begin{array}{l}\text { 非標準化 } \\
\text { 係数 }\end{array}$ & $\begin{array}{l}\text { 標準化 } \\
\text { 係数 }\end{array}$ & $t$ 值 & 内 \\
\hline$X_{1}$ & インターネットユーザー数 & $1.00 \mathrm{E}-03$ & 0.29 & $12.79 * *$ & $\begin{array}{l}\text { 各国のユーザー数を都市，地域ごとに人口 } \\
\text { 割合から比例配分している。 } \\
\text { 単位は (万人) としている。 }\end{array}$ \\
\hline$X_{2}$ & 新大陸英語使用国ダミー & 1.77 & 0.31 & $12.69 * *$ & $\begin{array}{l}\text { アメリカ合衆国, カナダ, オーストラリア } \\
\text { の各都市, 地域および国に } 1\end{array}$ \\
\hline$X_{3}$ & カリフォルニア州ダミー & 10.66 & 0.52 & $20.24^{* *}$ & アメリカ合衆国カリフォルニア州に 1 \\
\hline$X_{4}$ & ニューヨーク州ダミー & 6.86 & 0.33 & $16.07^{* *}$ & アメリカ合衆国ニューヨーク州に 1 \\
\hline$X_{5}$ & IT 産業集積地ダミー & 1.72 & 0.14 & $5.49^{* *}$ & 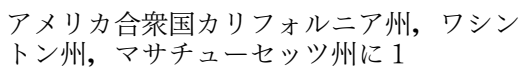 \\
\hline$X_{6}$ & 日本地域ダミー & -0.86 & -0.07 & $-3.38^{* *}$ & 日本の東京 23 区以外の地方に 1 \\
\hline$X_{7}$ & $\begin{array}{l}\text { 新大陸スペイン・ } \\
\text { フランス語使用国ダミー }\end{array}$ & -0.48 & -0.05 & $-2.51^{*}$ & $\begin{array}{l}\text { アメリカ合衆国 (スペイン語使用人口割合 } \\
\text { 分), カナダ(フランス語使用人口割合分), } \\
\text { メキシコに } 1\end{array}$ \\
\hline$\alpha$ & 定数項 & 0.03 & - & 0.4 & \\
\hline & 決定係数 & \multicolumn{3}{|c|}{0.98} & \\
\hline \multicolumn{2}{|r|}{ 自由度調整済み決定係数 } & \multicolumn{3}{|c|}{0.98} & \\
\hline
\end{tabular}

（注） $* *$ : 有意水準 $1 \%$ レベルで有意 $*$ : 有意水準 $5 \%$ レベルで有意

とがわかる。

4）日本地域ダミーはマイナスの值をとっていることから，日本を地方で区切って見た場合，そ の Globality $\left(G_{i j}\right)$ はインターネットユーザー数に比べて少ないことがわかる。将来的にこ れら対象としている圈域の中で序列を落とす可能性がある。

5）新大陸スペイン・フランス語使用国（今回の分析ではアメリカ合衆国スペイン語使用人口 割合分, カナダフランス語使用人口割合分, メキシコが該当) ダミーがマイナスの值をとっ ていることから，新大陸の欧州言語を使用している国の Globality $\left(G_{i j}\right)$ は，その言語を使 用している欧州の国の Globality（ $\left.G_{i j}\right)$ より低いということが明らかになった。

\section{5. ま と め}

本研究では, IT 化が都市にもたらす影響の一つとして, 言語の違いによる抵抗に着目した。そ して 5 つの言語圏ごとに，どの都市にどれだけのショップサイトが集中しているかを，検索エン ジン Google を用いてショップサイトの所在地を調査し, 明らかにした。そしてランクサイズグラ フを用いて人口割合との比較を行い，都市序列変化の可能性を検討した。さらに言語の違いが抵 抗とならなかった場合を考慮し，各都市の Globality $\left(G_{i j}\right)$ の要因分析を行った。具体的に得られ た成果は下記の通りである。

1）もともと中央集権型と言われる日本やフランスではショップサイトが人口以上に首都圏に 集中していることから, サイバーウォークは首都圏に集中すると類推され， IT 化により一 
極集中がさらに助長される可能性があることが明らかとなった。

2）これに対し，現在の都市分布自体が機能分散型と言われるアメリカ，ドイツでは，IT 化に より現在よりさらに分散化が進む可能性があることが示された。

3）スペインでは文化的な背景の異なるマドリード，バルセロナへの二極化がさらに進展する と考えられる。

4）今回の結果から，もともと実空間において一極集中型であっても，また分散型であっても， サイバー時代においてはその傾向がより顕著になるよう序列の変化が進むことが類推され る。

5） Globality $\left(G_{i j}\right)$ にはインターネットユーザー数や IT 産業集積が影響していることが明ら かとなった。

6) Globality $\left(G_{i j}\right)$ はアメリカが高く，その中でも特にカリフォルニア州，ニューヨーク州が 高くなっており世界からアクセスされるようになる潜在的な可能性が高いことがわかっ た。

7）論文中には紙数の制約から記載できなかったが，商品項目ごとに分析結果は同一ではな かった。例えば，日本語圈，フランス語圏では，本，音楽，DVD などで都市圏の占めるサ イト数割合が高く, 食品・飲料の項目で地方のサイト数割合が高かった。特にフランス語 圏では飲料の項目で，ワインで有名なボルドーのサイト数割合が高くなる傾向が見られる など，特産品の影響が見られた。また，ドイツ語圏では DVD，衣類の項目においてスイス のサイト数割合が高く，スペイン語圏では，音楽，健康・美容の項目においてアメリカの サイト数割合が高いなど，商品項目によっては国境ではなく，言語圏が新たな境界となり うることを類推させる結果も散見された。

以上のことから, 本研究で問題意識とした IT 化による世界での都市序列変化の可能性は, サイ トの立地という現象に着目するだけでも検討と類推を行うことが可能であり，一定の情報を提供 することができたといえる。

なお，今後の課題として次のようなことが挙げられる。

1）本研究での分析は (1) 言語バリアが強固な場合と，(2) 言語バリアが存在しない場合のあ くまで端点としての両極端でしかなく，近い将来における現実の世界はこの中間のどこか に存在する。さらに詳細な検討を行うには，国家ごとの言語教育に留まらず，言語戦略も 含めた新たな視点に基づく検討が求められる。デジタルデバイドを克服するための議論は 盛んであるが，それに留まらずランゲージデバイドというものに関する意欲的な取り組み が必要となろう。

2） サイバースペース上の多くのショップは，実空間にもショップを持っており，両空間にお いて所在地の相違があると考えられる。将来の都市序列を予測するにあたって，その相違 がどのような条件の下で発生しているかを明らかにする必要がある。また，今回の分析結 果から商品項目による条件の相違も予想され，これらの分析は今後の課題である。 
3）本研究では取り組みの端緒として，サイトの存在（数）と所在地に関する一時点での検討 のみを行っている。現在までの立地研究が，立地数の単純な分析から従業者数，売上高な どの多様な指標を考慮し，時系列的な拡がりを伴って発展してきたように，より多面的な 指標に基づく長期的なデータの蓄積，分析が求められる。

\section{参考 文 献}

［1］馬場健司，“情報通信技術による交通-コミュニケーション行動の補完と代替一オフィスにおける業務 ミーティングプロセスを考慮して—”、『土木計画学研究・論文集』No. 17, 1995 年, pp. 163-168.

[2 ] Brotchie, J., Newton, P., Hall, P. and Nijkamp, P., "The future of urban form, The impact of new Technology,” pp. 1-14, Croom Helm Ltd, 1985.

～ 3 ］ Castells, M., (大澤善信訳)『都市・情報，グローバル経済』青木書店，1999 年，p. 185.

［4］富士通総研 HP：インターネットショッピング調査 http://www.fri.fujitsu.com/hypertext/fri/cyber/shopping.

[5] Graham, S., The cybercities reader, Routledge, 2004.

[6 ］K’s Production 編著『Google の秘密』ソフトマジック出版, 2003 年.

[ 7 ] Leigh, N., "People versus place," Ed. by Wheeler, J. and Aoyama, Y., Cities in the telecommunication age, Routledge, 2000, pp. 302-332.

[8] Mitchell, W., e-topia, the MIT press, 1999, p. 24.

[9］ MY COM PC WEB HP：ニュース「世界のサーチエンジン利用率で google が第一位」 http://pcweb.mycom.co.jp/news/2002/04/18/18.html.

[10］中村良平・田㴊隆俊『都市と地域の経済学』有斐閣，1996 年，pp. 42-46.

［11］日本情報処理開発協会編『情報処理白書 2002』コンピュータ・エージ社出版，2002 年.

［12］ 大塚時雄・染谷広幸・実積寿也・三友仁志，“情報通信技術が買物交通需要パターンに与方る影響の分析 一学生の購買行動を中心として一”,『地域学研究』Vol. 34, No. 1, 2003 年, pp. 265-284.

[13］大矢正樹, “携带電話が消費行動に与元る影響について”, 『土木計画学研究・講演集』No. 27, 2003 年, CD-ROM 版.

[14] Sassen, S., Global networks, linked cities, Routledge, 2002, p. 98.

［15］佐藤仁志・太田 充，“テレコミューティングの普及と都市構造に関する研究”、『日本都市計画学会学術 研究論文集』No. 35, 2000 年, pp. 1051-1056.

[16] Shibusawa, H., "Spatial structure of virtual cities-Modelling of a system of cities in physical space and cyberspace-," Studies in Regional Science, vol. 29, No. 1, 1998, pp. 147-157.

[17] Special Issue, "Consumers in cyberspace," Journal of the Consumer Psychology, Vol. 13, No. 1 \& 2 , 2003.

［18］田北俊昭・湯沢 昭・須田 熙, “ニューメディアと交通の代替性を考慮した社内および社外間情報メ ディア選択モデル”、『土木計画学研究・論文集』No. 12, 1995 年, pp. 93-99.

[19］谷口栄一・秦健太郎, “E コマースの影響を考慮した都市内貨物車交通施策に関する研究”, 『土木計画学 研究発表会』No. 28, 2003 年, CD-ROM 版.

２0］谷口 守・阿部宏史・蓮実綾子，“サイバーウォークにおける空間抵抗特性とそのタウンウォークとの代 替性”、『土木計画学研究・論文集』2003 年, pp. 477-483.

［21］谷口 守・武嶋哲史・阿部宏史，“交通・情報面での機会均等化が都市活動特化に及ほす可能性”、『土木 計画学研究・論文集』No. 17, 2000 年, pp. 211-218.

［22］塚井誠人・奥村 誠, “代替性・補完性を考慮した業務交通と通信パターンの重力モデル”, 『日本都市計 画学会学術研究論文集』No. 34, 1999 年, pp. 85-90. 


\title{
The New Order of World Cities in the Information Era under Language Barriers
}

\author{
— Study on Shopping Behavior through E-Commerce- \\ Mamoru TAniguchi*, Ryoji Matsunaka* and Ryosuke Ando**
}

The barrier presented by distance has gradually been removed by high-speed transportation systems over the last century. As a result, hub cities have experienced economic growth. In other words, hinterland of each city has been reformed by these new transportation systems. It is needless to say that spreading information technologies (IT) open the door for new world, namely it could cause more drastic changes on the order of world cities. In order to achieve an efficient infrastructure and an affluent society, the conformational changes occurring in societies and regions as a result of the new technology must be examined beforehand.

The objective of this study is to estimate the changes of the order of world cities, caused by distance free cyber-space, that are created by IT. A couple of analyses based on different assumptions are examined below.

1) Language barriers are assumed to be the greatest obstacles to the exchange of information. To estimate the new order of cities in each language unit, composition ratio of the demographics and the number of net sites are compared.

2) From a global point of view, no barrier is assumed in the world. The concept of globality is defined, as the potentiality to invite more cyber access to that city. Model analysis is also examined to clarify factors to affect globality.

From these analyses, it is clarified that each language unit shows different future. More concentration could occur in Japan and France, and more dispersion could occur in Germany. It is also found that the complex of IT industries in the U.S.A. is likely to obtain higher globality. Therefore, it is said that the order of world cities, namely city rank, could change in the world in information era.

JEL classification: R12, R14

Keywords: Information Technology, Order of cities, E-Commerce, Language barrier, Globality

\footnotetext{
* Faculty of Environmental Science and Technology, Okayama University, 3-1-1 Tsushima-naka Okayama-shi Okayama-ken, Japan

** Graduate School of Natural Science \& Technology, Okayama University, 3-1-1 Tsushima-naka Okayama-shi Okayama-ken, Japan
} 